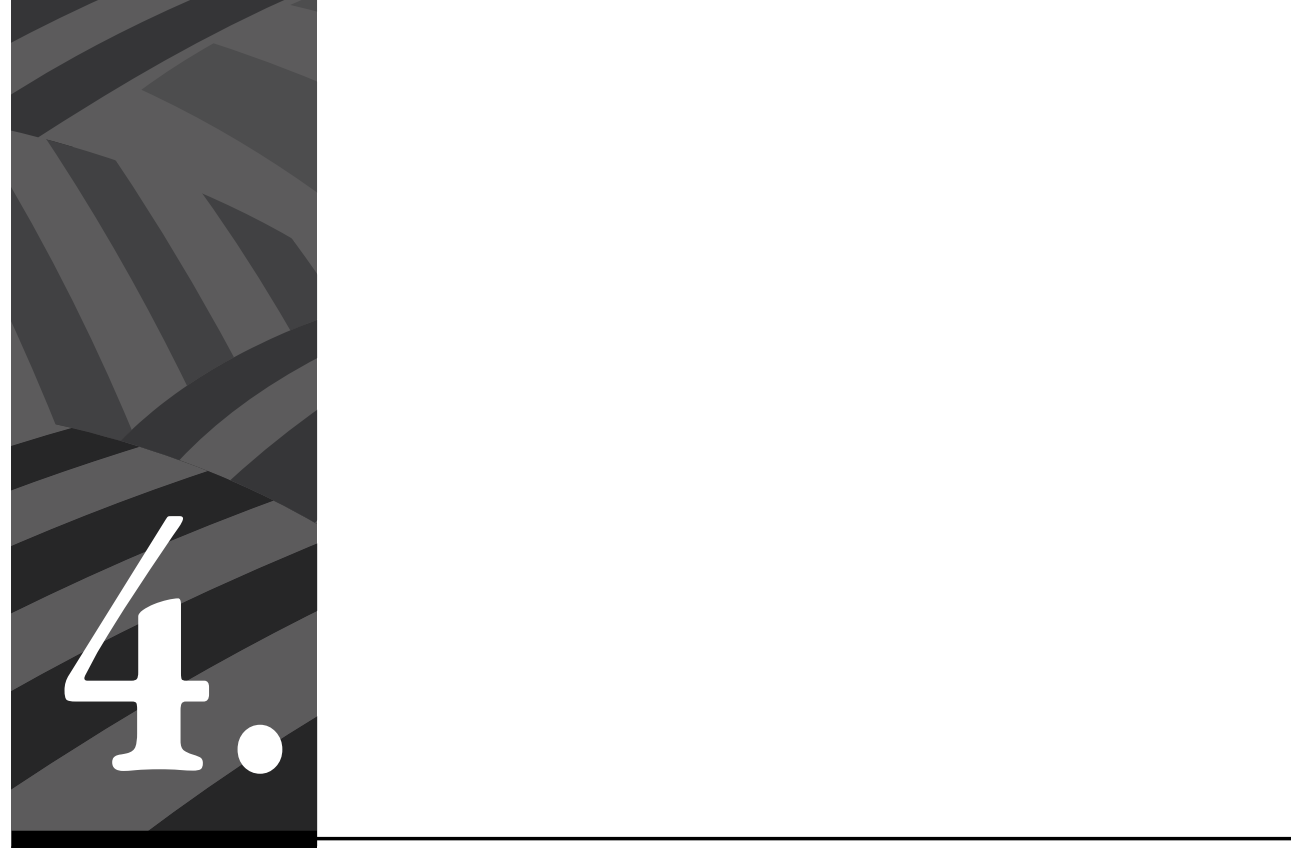

Negros, LGBTI e periféricos:

o impacto das relaçóes entre movimentos na consolidação de ativismos interseccionais 


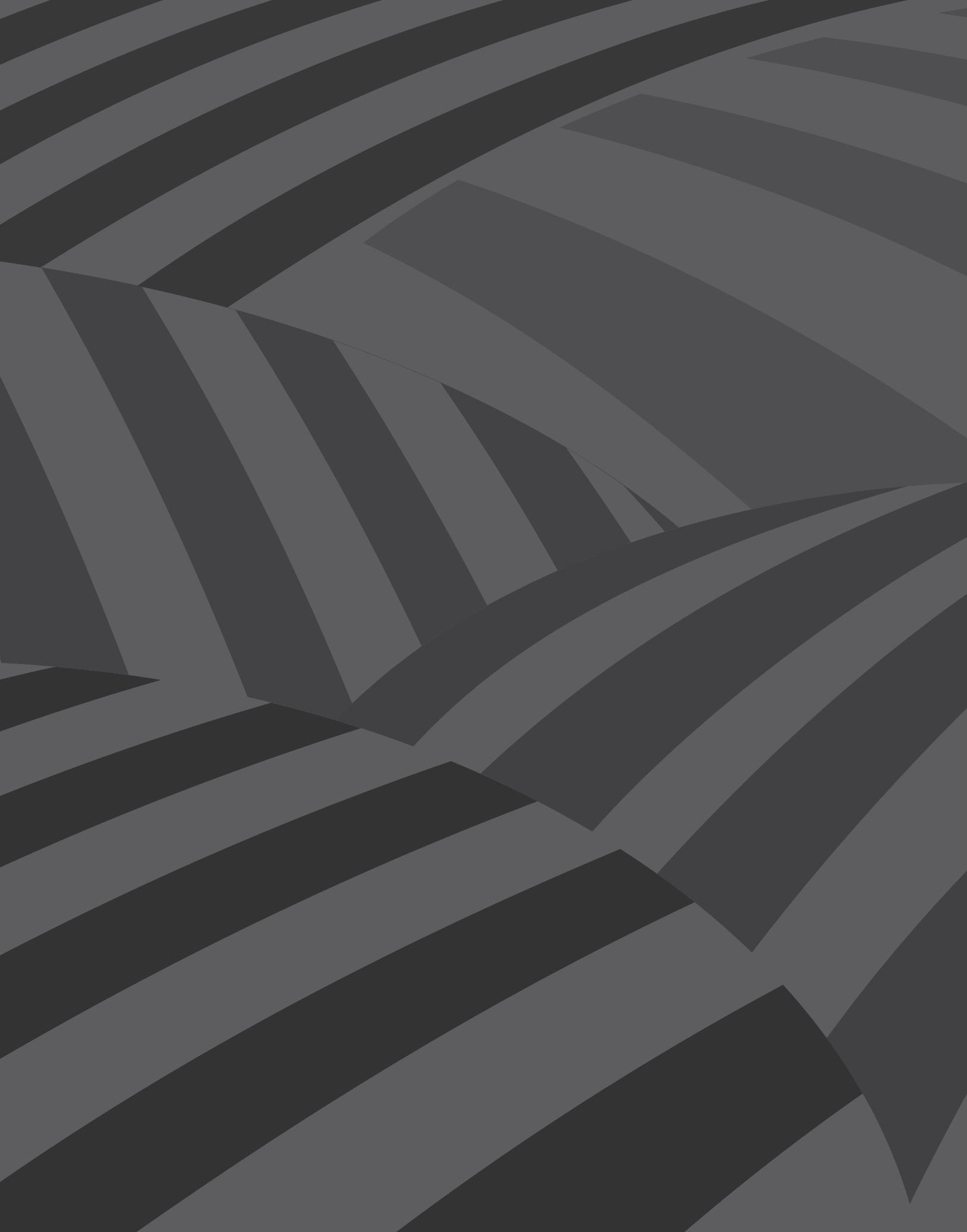




\section{Negros, LGBTI e periféricos: o impacto das relaçóes entre movimentos na consolidação de ativismos interseccionais}

Por Vinícius Zanoli*

Resumo: Neste artigo, baseado em investigação etnográfica realizada entre 2015 e 2019, discuto os impactos das relações entre movimentos sociais na consolidação de um ativismo interseccional. Trata-se de uma análise das redes nas quais atua o Aos Brados, um coletivo LGBTI, negro e da periferia fundado há mais de 20 anos em Campinas (São Paulo, Brasil). Aqui, demonstro como o grupo, ao circular por uma teia que conecta atores e movimentos distintos, passa a aderir e ressignificar noções e práticas políticas que circulam em tal rede. Ao analisar as atividades culturais que passaram a realizar a partir de 2008, evidencio a importância das relações entre ativismos na consolidação de uma identidade política coletiva e de um modo de atuar que valoriza as interseccionalidades, fato pouco explorado pela literatura sobre movimento LGBTI, em particular, e sobre movimentos sociais, de modo geral.

Palavras chave: Movimentos Sociais; Movimento LGBTI; Movimento Negro; Ativismo Interseccional.

\section{Black, LGBTI and from the Favelas: The Impact of the Relationships between Movements in the Consolidation of Intersectional Activisms}

Abstract: In this article, based on an ethnographic investigation carried between 2015 and 2019, I address the impact of the relationships between social movements in the consolidation of an intersectional activism. The analysis is centered on the political networks of a black, peripheric and LGBTI organization: Aos Brados; founded in 1998 in Campinas (São Paulo, Brazil). Here, I demonstrate how, while moving through a web that connects different movements, the group reframes notions and practices circulating in this network. Through the analysis of the cultural activities

* Antropólogo, doutor em Ciências Sociais na área de Estudos de Gênero e mestre em Antropologia Social, ambos pela Universidade Estadual de Campinas (Unicamp), Brasil. Autor do livro Bradando contra todas as opressões! Ativismos LGBT, negros, populares e periféricos, (ed. Devires, 2020). Tem interesse na área de Antropologia da Política e experiência de pesquisa com movimentos sociais, movimento LGBT e movimento negro no Brasil, com foco nas relações entre movimentos e nas intersecções Estado-ativismo. Contato: vzanoli@gmail.com. 
that the group organizes since 2008, I reveal the significance of the relationships between social movements in the strengthening of a collective political identity and a form of acting that invests in intersectionality; a fact underexplored in the literature.

Keywords: Social Movements, LGBTI Movement, Black Movement; Intersectional Activism.

Cómo citar este artículo: Zanoli, Vinícius (2020). Negros, LGBTI e periféricos: o impacto das relações entre movimentos na consolidação de ativismos interseccionais. Revista Controversia, 215, 111-157.

Fecha de recepción: 22 de febrero de 2020

Fecha de aprobación: 13 de junio de 2020

\section{Introdução}

lém de seu potente uso na teoria social contemporânea, a abor-
dagem interseccional tem extravasado os limites das universida-
des, chegando, cada vez mais, às ações coletivas. Os ativismos recentes no Brasil têm sido marcados pelo uso de categorias como "interseccionalidade" ou pelo "combate a todas as formas de opressão" (Rios, Perez, e Ricoldi, 2008; Zanoli, 2020). A literatura contemporânea sobre a temática acentua a importância dos feminismos negros e o papel das jovens negras em fazer com que o discurso político que se atenta à inter-relação entre opressões ultrapasse os limites da "sociedade civil", isto é, de formas tradicionais de ativismo que apostam em mudanças "democráticas" a partir de relações menos contenciosas com setores estatais (Alvarez, Jeffrey, Thayer, Baiocchi, e Laó-Montes, 2017). Além disso, ressaltam o investimento em uma política que articula as redes e as ruas e que dá menos importância às relações com instâncias governamentais (Gomes, 2019, Rios e Maciel, 2017-2018).

As diferentes abordagens interseccionais levam em conta as conexões e relações entre distintas marcas de diferença, seus impactos em modos como as desigualdades são configuradas e a maneira como tais diferenças estruturam distintos contextos políticos e sociais (Brah, 1996, Crenshaw, 1989). Por esse motivo, o termo tem sido aplicado também por outras formas de ativismo para descrever suas clivagens políticas 
(Rios e Maciel, 2017-2018). Assim, sujeitos ligados ao movimento LGBTI, por exemplo, principalmente quando marcam sua relação com ativismos negros e feminismos negros, mas também com sujeitos que transitam por outros movimentos sociais, passam a empregar essa terminologia. Outros, mesmo que não tenham aderido ao uso do termo, têm ressaltado a importância de lutar contra distintas formas de opressão (Bulgarelli, 2018, Facchini, 2018, Zanoli, 2020).

Ademais, estudos recentes ressaltam o aumento das relações ativistas que resultam em aprendizados e trocas (Lopes e Heredia, 2014). Eles sublinham também que, com o passar do tempo, movimentos tidos como mais gerais, como sindicatos e partidos políticos, passaram a conter em suas estruturas secretarias e setoriais ligados a movimentos denominados de "identitários" ou "culturais”, como movimentos feministas, negros e LGBTI, por exemplo.

Este artigo procura contribuir com essa literatura, partindo da análise das conexões entre as relações políticas, modos de atuação, produção de significado e o contexto político. Tal empreitada foi realizada a partir de uma etnografia com foco no Aos Brados - um grupo ativista LGBTI, negro e da periferia ${ }^{1}$ que, desde Campinas, ${ }^{2}$ atua a partir de uma rede que conecta ativismos LGBTI, negros, populares e periféricos, como: comunidades religiosas de matriz africana, grupos ativistas culturais

1 Neste artigo, periferia é uma categoria êmica, isto é, uma categoria produzida pelos próprios interlocutores. No Brasil, esse termo tem sido utilizado para se referir a regiões urbanas geralmente afastadas do centro da cidade. Esses locais são também costumeiramente mais pobres e carecem de uma série de equipamentos e políticas públicas. Algumas vezes, o termo é utilizado por meus interlocutores como sinônimo de favela. No estado de São Paulo, o uso político do termo está fortemente associado à literatura marginal, ao movimento hip-hop e à politização da ideia de cultura de periferia (Nascimento, 2011).

2 Metrópole com mais de um milhão de habitantes situada no estado de São Paulo, no Sudeste brasileiro, distando pouco mais de $100 \mathrm{~km}$ da capital do estado. 
negros e da periferia, coletivos LGBTI, partidos políticos, centrais sindicais, dentre outros. ${ }^{3}$

Busco contribuir com a compreensão das trocas e aprendizagens entre movimentos sociais, sublinhando que esse processo foi influenciado por relações estabelecidas entre movimentos, principalmente quando da proliferação de políticas participativas durante o governo Lula (20032011). Nesse período, foram criados ou consolidados uma série de canais de interlocução entre Estado e ativismo e no qual militantes passaram a compor os quadros da administração pública em distintos níveis (Aguião, 2018, Feitosa, 2019, Gomes, 2019, Mello, Walderes, e Maroja, 2012, Rios, 2014). O período é marcado também pela proliferação de organizações que tratam de questões que perpassam mais de um campo movimentista, pela consolidação de um discurso de combate a todas as formas de opressão e pelo compartilhamento de pautas entre movimentos sociais tidos como distintos. Portanto, se em meados dos anos 1970, discussões sobre gênero, sexualidade e raça em partidos políticos, sobre sexualidade no movimento negro e sobre raça e racismo no movimento LGBTI eram vistos por alguns como "separatismo" (Gonzalez, 1982, MacRae, 1990), na atualidade, elas se mostram centrais à existência de tais movimentos.

Uma das hipóteses da pesquisa da qual resulta este artigo é a de que, hoje, estamos acompanhando não apenas fluxos horizontais do feminismo - nos quais, discursos e práticas produzidas no bojo dessa forma de ativismo têm extravasado os limites do próprio feminismo, bem como daquilo que tem sido conceituado como "sociedade civil" (Alvarez, 2014) -; é possível que outros movimentos sociais, como o movimento negro, por exemplo (Lima, 2020), estejam passando por um processo parecido, o que pode ajudar a explicar essa intensa circulação entre eles.

3 Os dados foram produzidos, principalmente, por meio de observação participante realizada entre 2015 e 2018, com o objetivo de mapear a rede de atores com os quais o Aos Brados se relaciona, bem como as frentes e campos movimentistas nos quais se insere. Realizei também análise documental no acervo do grupo e entrevistas em profundidade com fundadores e membros atuais. 
Sônia Alvarez (2014) e seus colaboradores (2017) propõem que pensemos além do que tem sido conceituado enquanto "sociedade civil", visto que esse termo é limitante em dois sentidos. Em primeiro lugar, porque foi construído, muitas vezes, em oposição ao Estado e, como a literatura recente nos mostra, essa abordagem não condiz com a realidade concreta, nem no Brasil, nem na América Latina. Em segundo lugar, porque limita o modo como pensamos formas de atuação menos institucionalizadas, como os ativismos online e o uso de mídias digitais, além de formas tidas enquanto "menos cívicas”, como protestos não pacíficos, por exemplo. Ou seja, podemos pensar nesse extravasamento dos discursos e práticas, tanto em direção ao Estado (verticalmente) quanto para outras direções, dentro e fora dos limites do que tem sido conceituado como "sociedade civil”. Ademais, Alvarez (2014) propõe também que o que temos chamado de movimentos sociais são "campos discursivos de ação” que englobam uma gama de atores distintos relacionados por meio de "redes político-comunicativas" que "se entrelaçam em malhas costuradas por cruzamentos entre pessoas, práticas, ideias e discursos (Alvarez, 2014, p. 18)”. Desses campos, fazem parte tanto atores institucionais quanto atores menos institucionalizados. Além disso, ela ressalta que o que flui por redes em um “campo” pode vir de relações e coligações com outros campos movimentistas.

Neste artigo, proponho que o debate recente sobre o que tem sido chamado de "especificidades" - denominado aqui de ativismo intersecional - tem negligenciado o papel dos movimentos sociais na construção dessas "redes político-comunicativas", dando ênfase ao papel do Estado, não apenas enquanto principal interlocutor dessas redes, mas também como principal articulador. A pesquisa aqui apresentada demonstra que existem outros fatores para além do papel estatal, como os sujeitos que atuam em mais de um movimento social e que fundam grupos, frentes ou redes que articulam esses distintos movimentos em sua atuação política, como é o caso do Aos Brados. Ou seja, não só o Estado, mas esses sujeitos ligados a diversos movimentos sociais têm papel central na consolidação de redes que conectam distintas formas de ativismo e que fazem circular repertórios e enquadramentos específicos. 
Aqui, a partir da atual forma de atuação do grupo, as apresentações culturais, ${ }^{4}$ exploro o modo pelo qual seus ativistas, ao circularem por campos discursivos de ação que articulam políticas variadas - como a política LGBTI, o hip-hop, a luta contra o racismo e a conservação da cultura e a tradição negra -, mobilizam um conjunto de repertórios ${ }^{5}$ de atuação que é aprendido no contato com esses campos. Portanto, se, como aponta Tilly (1993), é na e por meio da luta que os repertórios de atuação são aprendidos e atualizados, é por meio do envolvimento dos ativistas do Aos Brados nesses distintos campos discursivos de ação que as atividades culturais ${ }^{6}$ são forjadas enquanto forma de luta. Tais atividades dizem respeito à segunda fase de atuação do Aos Brados, que se iniciou em 2008, quando o grupo passou a ter um contato mais orgânico com o que chama de ativismo cultural negro.

O olhar para tais atividades segue na esteira de debates da antropologia política brasileira, que tem ressaltado a importância da compreensão do "ponto de vista nativo na política”. Essa compreensão nos permite não apenas pensar como a política é pensada e vivida, mas também como se constitui a partir de relações em nível local (Palmeira e Barreira, 2004). Assim, ao apresentar as mudanças na forma de atuar do grupo, o artigo procura compreender as próprias noções êmicas de cultura, buscando, a partir disso, demonstrar o impacto das relações entre os ativistas - sem desconsiderar as relações com o Estado - nos modos de atuar e de dar sentido à luta que circulam pela rede analisada. Ainda

4 Neste artigo, as categorias êmicas serão grafadas em itálico. Ainda assim, nem todas serão objeto de escrutínio da análise, apenas que seu uso mais corrente por parte dos ativistas será demarcado. Quando forem analisadas, isso será ressaltado no texto.

5 Apresento a definição mais adiante no texto.

6 A diferença entre atividade cultural e apresentação cultural está no modo como são realizadas e organizadas: as atividades culturais são eventos que congregam uma série de apresentações culturais, como danças, performances de drag queens, entre outros. Esse termo é empregado por outros grupos que se concebem enquanto ativistas culturais para descrever suas atividades, geralmente com uso de música e apresentações artísticas (Giesbrecht, 2011b). 
que o uso da ideia de cultura não seja uma novidade no que diz respeito ao movimento negro (Silva, 2009), ela passou a ser explorada por ativistas LGBTI apenas recentemente e a análise de seus usos por essa forma de ativismo ainda é incipiente (Braz, 2014). Aqui, ao tomar as atividades culturais como a principal forma de atuação do Aos Brados, procuro demonstrar como elas são uma das expressões do ativismo interseccional do grupo, que relaciona não apenas repertórios, mas também enquadramentos advindos do movimento negro e dos movimentos culturais de periferia e ressignifica suas próprias maneiras de atuar e de dar sentido à luta.

Considerando as discussões acima, o artigo foi organizado da seguinte maneira: na próxima seção, apresento alguns dos conceitos fundamentais empregados; em seguida, reitero que as relações entre movimento negro e movimento LGBTI não são fenômenos recentes, contudo, foram pouco trabalhadas pela literatura; depois, realizo um debate crítico com trabalhos recentes sobre ativismo LGBTI, demonstrando que, ao procurar entender processos de "especificação" do sujeito político do movimento, esses trabalhos privilegiam as relações entre movimento e Estado, dando pouca relevância às relações entre os ativismos, o que pode deixar de lado um dos principais fatores que leva ativistas a fundarem grupos voltados a tais "especificidades"; na sequência, apresento duas das atividades realizadas pelo Aos Brados, demonstrando como, a partir delas, o grupo aciona repertórios de atuação presentes no movimento negro, ao mesmo tempo que ressignifica outros que já empregava.

\section{Definindo conceitos fundamentais}

O conceito de repertório foi primeiramente empregado por Charles Tilly em 1977 para descrever formas de ação coletiva (Bringel, 2012). De acordo com Tilly, “a palavra repertório identifica um conjunto limitado de rotinas que é aprendido, compartilhado e traduzido em ações por meio de um processo relativamente deliberado de escolhas (Tilly 1993, 
p. 264, tradução minha)". ${ }^{7}$ Ainda que tenha sofrido mudanças ao longo da carreira de Tilly, o conceito se manteve fortemente ligado a ideias que representam movimentos sociais enquanto ações coletivas contenciosas. Como uma série de autores tem ilustrado, essa ideia está ligada a perspectivas que compreendem movimentos sociais e Estado como opostos (Banaszak, 2005). Entretanto, estudos recentes têm indicado que movimentos sociais estão envolvidos em complexas relações com agências governamentais e funcionários públicos (Abers, Silva, e Tatagiba, 2018, Alvarez, 2014, Alvarez, Jeffrey, Thayer, Baiocchi, e LaóMontes, 2017, Zanoli, 2020).

Desse modo, seguindo as discussões de Sonia Alvarez (Alvarez, 2014), movimentos sociais são compreendidos aqui como "campos discursivos de ação” formados por sujeitos que ocupam posições tanto dentro quanto fora do aparelho estatal. Ademais, parto de discussões que apontam para a necessidade de adaptação do conceito de repertório. Assim, como proposto por Rebecca Abers, Lizandra Serafim e Luciana Tatagiba (2014), além de repertórios contenciosos é possível falar em repertórios colaborativos. Nesse sentido, pode-se compreender o termo como uma metáfora que se refere a formas de ação de maneira ampla. Portanto, tomo repertórios como um conjunto de formas de atuação utilizado por ações coletivas para propor, pressionar por, ou realizar mudanças sociais, políticas e culturais baseadas em projetos e visões de mundo dos ativistas. Procuro demonstrar assim, como as relações entre os ativismos têm impacto não apenas nos repertórios empregados, mas também como essas relações e a utilização e adaptação de repertórios mais empregados por outros movimentos sociais impactam no modo como os ativistas dão sentido à luta.

Para dar conta desses processos de produção de significado, os estudos de movimentos sociais têm utilizado, principalmente, a "perspectiva

7 Original: "the word repertoire identifies a limited set of routines that are learned, shared, and acted out through a relatively deliberate process of choice.". 
dos frames", ou "enquadramentos". David Snow, Burke Rochford, Jr., Steven K. Worden e Robert Benford (1986) desenvolveram tal perspectiva sob influência da abordagem interacionista simbólica acerca dos frames empreendida por Goffman (1974). Como nos demonstram alguns de seus fundadores, essa abordagem passou a ser central na análise da produção de sentidos por parte dos movimentos sociais (Benford e Snow, 2000, Snow, Benford, McCammon, Hewitt, e Scott, 2014). Podemos definir um frame como modos de definir demandas, projetos e objetivos de movimentos sociais (Abers, Serafim, e Tatagiba, 2014). Cabe ressaltar ainda, que este trabalho leva em conta as críticas de Alvarez (2014) à ideia de "processos de enquadramento". Para essa autora, essa perspectiva analisa a produção de sentido em meio aos movimentos sociais apenas a partir de sua faceta estratégica, isto é, buscando convencer outros sujeitos de que sua causa é legítima. Esse modo de olhar para os enquadramentos esquece que os sentidos são disputados no interior das redes político-comunicativas e que eles não são produzidos apenas com o objetivo de conquistar resultados políticos, sendo também fruto das vivências dos sujeitos que compõem os movimentos e do fato de que ativistas são produtores de conhecimento sobre suas próprias realidades (Gomes, 2019).

Finalmente, um terceiro conceito importante para esta discussão é a ideia de "estrutura de oportunidades políticas". Segundo Donatella della Porta e Mario Diani (2006), os debates acerca desse conceito foram desenvolvidos por pesquisadores ligados à teoria do processo político (TPP). Como tais pesquisadores apontam, essa perspectiva "presta atenção mais sistemática ao ambiente político institucional em meio ao qual os movimentos sociais operam (della Porta e Diani, 2006, p. 16, tradução minha). ${ }^{9}$ Segundo Abers, Silva e Tatagiba (2018):

8 Não há consenso na tradução do termo para o português, alguns cientistas sociais preferem o uso do termo em inglês, outros têm optado por traduzi-lo.

9 Original: "pays more systematic attention to the political and institutional environment in which social movements operate." 
A síntese da contribuição teórica da TPP para análise do contexto político se expressa no conceito de estrutura de oportunidades políticas (EOP), através do qual (sobretudo em sua dimensão "estrutural") se buscava identificar e analisar condições político-institucionais que afetariam de maneira abrangente e generalizada processos de construção, ação e resultados dos movimentos sociais (Abers, Silva, e Tatagiba, 2018, p. 24).

Desse modo, o conceito de estrutura de oportunidades políticas nasceu dessas preocupações, ao procurar compreender como o ambiente político influencia ações coletivas. Contudo, muitas vezes, essa literatura, como apontam Abers, Silva e Tatagiba (2018), ao se preocupar com o contexto político, acaba tomando-o apenas como um conjunto de forças que permitem ou constrangem a atuação dos movimentos sociais. Frequentemente, isso é feito sem levar em conta o próprio papel dos movimentos sociais na conformação de certos contextos políticos. Assim, ainda que continue utilizando tal noção, levo em conta as críticas acima citadas. Portanto, como proponho aqui, é possível pensar nas próprias relações entre os ativismos como uma das oportunidades políticas que fomentou a consolidação do que chamo aqui de ativismo interseccional.

\section{Aproximações e distanciamentos}

A literatura sobre movimento LGBTI no Brasil ressalta o surgimento do grupo Somos de São Paulo e do jornal Lampião da Esquina, em 1978, como importantes marcos do nascimento dessa forma de ativismo (Facchini, 2005, MacRae, 1990). Cabe ressaltar que, em seu início, o que chamamos hoje no Brasil de movimento LGBTI era denominado por seus ativistas de Movimento Homossexual Brasileiro (MHB). Durante os anos iniciais dessa forma de ativismo, compreendia-se que a categoria "homossexual" seria abrangente o suficiente para definir os sujeitos 
políticos que compunham o movimento. ${ }^{10} \mathrm{O}$ referido ano marca também a fundação do Movimento Negro Unificado (MNU), uma importante aliança nacional de combate ao racismo articulada por uma série de organizações e com a participação de renomados intelectuais negros do período, como Lélia Gonzalez e Abdias do Nascimento (Gonzalez, 1982, Pereira, 2008).

O ano de fundação não é o único fato que conecta o Somos ao MNU. MacRae (1990) ressalta que ambos os movimentos eram aliados importantes e chama atenção para o fato de que a primeira participação do Somos em uma passeata ocorreu em 1979, no dia Nacional da Consciência Negra, organizado pelo MNU. Essa participação teria sido instigada por um membro do Somos que fazia parte da organização trotskista Convergência Socialista (CS), uma das correntes políticas que fundou o Partido dos Trabalhadores (PT) e, mais tarde, o Partido Socialista dos Trabalhadores Unificado (PSTU). MacRae entende as relações entre o movimento negro e o movimento homossexual como fruto da influência do Lampião da Esquina e da própria CS. Rios (2014) também ressalta a importância da esquerda brasileira, principalmente da CS e da revista Versus, na consolidação do MNU no período.

Apesar disso, Edward MacRae (1990) e Lélia Gonzalez (1982) reforçam que setores dessa vertente política compreendiam as questões de movimentos como o homossexual, o negro e o feminista como secundárias. Por isso, acreditavam que elas deveriam ser tratadas apenas depois de conquistadas as transformações sociais e econômicas com foco na classe trabalhadora. Pelo fato de serem acusados por alguns de dividir a

10 Apesar disso, tensões internas existiam e sujeitos políticos como as mulheres lésbicas lutaram para que sua identidade fosse inserida na sigla do movimento (MacRae, 1990). Como demonstra Facchini $(2005,2018)$, essa sigla é instável e está em transformação constante: o MHB passou a ser chamado de Movimento de Gays e Lésbicas e, mais recentemente, de movimento LGBTI (de lésbicas, gays, bissexuais, travestis, transexuais e intersexo). Aqui, adoto LGBTI por ser a sigla mais usual pela maioria dos ativistas em período recente, sendo também a forma que o Aos Brados passou a adotar em período posterior a finalização da pesquisa de campo. 
classe trabalhadora, MacRae também acredita que muitos dos grupos tidos como minoritários se uniram estrategicamente, buscando fazer frente a essas acusações.

Com o fim do Lampião e do Somos, os anos 1980 marcam o início de uma nova fase do movimento LGBTI, caracterizada pela redução numérica dos grupos ativistas e pelo combate à epidemia de HIV/Aids (Facchini, 2005). Uma das mais importantes organizações desse período foi o Triângulo Rosa do Rio de Janeiro, conhecido por liderar a campanha pela inclusão da não discriminação por orientação sexual na Constituição de 1988 (Câmara, 2002).

O número de organizações LGBTI voltou a crescer durante os anos 1990. Nessa fase, sob o impacto das políticas de combate à epidemia de HIV/ Aids, parcela considerável dos grupos assumiu o formato de ONGs, engajando-se em parcerias com o Estado na implementação, avaliação e execução de políticas públicas. Outra característica desse período foram os processos de multiplicação e especificação do sujeito político do movimento, que são centrais a discussão aqui empreendida.

A multiplicação pode ser representada pela metáfora da "sopa de letrinhas”, que se refere à proliferação de orientações sexuais e identidades de gênero representadas na sigla do movimento (Facchini, 2005). Já especificação diz respeito a formulação de sujeitos políticos que não estão associados apenas às referidas orientações sexuais e identidades de gênero, mas a outras marcas de diferença, como raça classe, gênero e sexualidade. $\mathrm{O}$ termo tem sido utilizado pela literatura brasileira para definir o que eu chamo de ativismo interseccional. Essa ideia deriva do discurso de ativistas ao apontarem que suas questões específicas como mulheres, como negros, ou como periféricos, por exemplo, são deixadas de lado ou pouco discutidas no que chamam de movimento hegemônico. Esse processo se insere naquilo que Hall (2001) define como “diferente lógica da diferença”. Nela, ao invés de pautar-se em identidades totais e fechadas em si mesmas que se diferenciam através 
do “ou”, a aposta está na "potencialidade de um e”, o que significa a lógica da junção preferivelmente à lógica binária” (Hall, 2001, p. 156). Essa aposta no "e” baseia-se na ideia de que identidades são constantemente negociadas a partir das posicionalidades que os sujeitos assumem. Como demonstra Djamila Ribeiro (2017), não se trata de um separatismo, mas de chamar atenção para a não universalidade dos sujeitos que um movimento diz representar. ${ }^{11}$

Ademais, no âmbito das políticas públicas, esse debate está pautado em discussões em torno da transversalidade e de leituras em torno de abordagens interseccionais ${ }^{12}$, impactando no surgimento de grupos e redes tidos como específicos. No entanto, ela é fruto também, como argumenta Muñoz (1999), da própria realidade dos sujeitos aqui estudados, que por serem LGBTI, periféricos e negros e atuarem em mais de um campo movimentista, precisam negociar suas diversas posicionalidades.

Desse modo, desde o surgimento do Somos até os dias atuais, tensões relativas às articulações entre relações de poder, diferenças e desigualdade se fizeram presentes. No começo dos anos 1980, questões relacionadas a gênero e a raça resultaram em cisões no Somos, originando o Grupo Lésbico-Feminista e o Grupo de Negros Homossexuais (MacRae, 1990). Nos anos 2000, redes e grupos ativistas voltadas ao que se con-

11 Como proponho em meu livro (Zanoli, 2020), para além da “lógica da junção”, encontrei também operando uma "lógica das alianças" pautadas no que chamei da potencialidade do "mas". Esta, para além de investir nas intersecções entre marcas da diferença e nas diferentes posicionalidades (ou seja, a referida potencialidade do “e”), dedica-se também a construir alianças entre sujeitos que, ainda que de modos diferentes e desiguais, compartilham condições de precariedade entre si (Butler, 2018).

12 Como nos mostra Aguião (2018), esses são dois conceitos em disputa no uso de ativistas LGBTI em sua relação com o Estado no Brasil. Muitas vezes, transversalidade aparece como uma leitura ativista das discussões acerca das interseccionalidades. Em outras, seu uso é feito de modo mais ou menos estratégico, com o objetivo de criticar o suposto academicismo do termo interseccionalidade. Em outros contextos, a ideia de transversalidade diz respeito a diálogos entre órgãos do governo que lidam com questões distintas, esses "diálogos transversais" teriam como objetivo produzir políticas públicas mais eficientes. 
vencionou chamar de "especificidades" emergiram, como a Rede Afro LGBT, criada em 2005, (Santos, 2015) e o Candaces (Coletivo Nacional de Lésbicas Negras Feministas Autônomas), fundado em 2007. No que diz respeito aos grupos, além do próprio Aos Brados, destaco a criação do Conexão G, na favela da Maré, no Rio de Janeiro (Lopes, 2011).

\section{Relações Ativistas}

Ainda que a fundação de alguns grupos date do início do movimento, há poucos estudos abordando tal temática. A maioria chega a descrever a existência de grupos de LGBTI negros, por exemplo, mas não os toma como foco. Um dos poucos trabalhos que narra o surgimento de um desses grupos é o de MacRae (1990), que relata uma cisão no Somos que dá origem ao Negros Homossexuais em 1980. Para este autor, as relações do Somos com o movimento negro e com o movimento feminista influenciaram a cisão que deu origem tanto ao Negros Homossexuais, quanto ao Grupo de Ação Lésbico-Feminista. Em sua discussão sobre a constituição da "identidade homossexual", MacRae argumenta que, nas reuniões de "identificação" do Somos, ao compartilhar as experiências de preconceito que seus membros sofriam, o grupo produzia o que seria uma "comunidade de iguais". Contudo, esse processo só era possível graças ao apagamento de outras diferenças e desigualdades, como as de raça e gênero, por exemplo. Por isso, o relacionamento do grupo com o movimento negro e o movimento feminista levou alguns dos membros a questionar posturas racistas e machistas dos membros do Somos, ou seja a questionar a ideia de que o grupo seria uma "comunidade de iguais”. Isso acabou por resultar nas referidas cisões.

É importante ressaltar que esses ativistas não eram críticos apenas ao racismo presente no movimento homossexual, mas também a posturas homofóbicas do MNU. Nesse sentido, é interessante notar como a circulação dos ativistas que fundaram o Negros Homossexuais em ambos os movimentos foi importante para a consolidação de uma postura crítica que buscasse relacionar suas realidades enquanto homossexuais e negros, fato que também me foi ressaltado por uma série de interlocutores 
durante a realização da pesquisa. Segundo MacRae, o grupo teve vida curta, mas foi importante na concretização de outros grupos negros LGBTI que surgiram posteriormente, como o Adé-Dudu, fundado em 1981 em Salvador.

Já trabalhos recentes, como o de Sílvia Aguião (2018), problematizam disputas internas do movimento LGBTI a partir da mobilização de ideias em torno das "especificidades", porém, não tratam propriamente das relações entre o que tem sido definido como ativismos distintos. Aguião chega a discutir a utilização de ideias relacionadas à soma de opressões e menciona também disputas ocorridas em conferências versando sobre quais sujeitos políticos do movimento seriam mais vulneráveis. No entanto, tais disputas são compreendidas pela autora mais como fruto das relações do movimento LGBTI com o Estado, do que como produto de intensas relações ativistas. Isso se deve, principalmente, porque sua pesquisa trata de um momento particular na história do movimento marcado pelo reconhecimento por parte do Estado de parcela das demandas advindas dos movimentos sociais.

Ademais, Aguião - seguindo as discussões de Paulo Vítor Leite Lopes (2011) sobre um grupo ativista LGBTI da favela da Maré no Rio de Janeiro - propõe que essas disputas e os processos de cisão delas resultantes seriam produto das relações com o Estado. Tanto para ela quanto para Lopes, o que explicaria o processo de especificação seria o fato de que, com o aumento da interlocução com o Estado, os grupos teriam que disputar entre si não apenas por financiamento, mas também por capital político. Nesse sentido, um coletivo teria mais chance de sucesso, se aderisse à gramática estatal que era pautada em noções como transversalidade e interseccionalidade. É interessante notar que, frequentemente, esses trabalhos problematizam pouco como o próprio aumento das relações entre os ativistas pode ter sido motor das pressões que fizeram com que a gramática da transversalidade e das interseccionalidades fosse adotada pelo Estado. Isto é, pensam em como os ativistas se adequam às linguagens do Estado, mas não discutem as possibilidades de o oposto também acontecer. 
De fato, parte considerável dos trabalhos sobre movimento LGBTI, bem como aqueles que tratam da trajetória do movimento negro ou de outras formas de ação coletiva que têm se relacionado politicamente e se movido pela teia que essa pesquisa busca analisar, parece tratar pouco das relações ativistas, tendo como foco principal as relações com o Estado. Principalmente no que diz respeito a estudos que tratam do período inaugurado com a redemocratização. Talvez, em momentos anteriores, isso fosse possível porque esses próprios movimentos tenham investido fortemente nessas relações com o Estado e, em consequência, em uma gramática estatal. Contudo, um olhar sobre os movimentos sociais que não tenha como foco as relações ativistas pode não dar conta dos processos políticos pelos quais passam as formas de ação coletiva no Brasil, visto que sozinhas as relações com o Estado não explicam o surgimento de grupos como o Aos Brados, nem as trocas entre os ativismos. Ademais, eles também deixam de fora uma série de grupos e coletivos que, mesmo no período das relações intensas com o Estado, não aderiram à atuação junto a órgãos e agências governamentais.

O que a pesquisa aqui realizada mostra é que, se as relações com o Estado têm importância nas categorias mobilizadas e nos repertórios de atuação empregados pelos movimentos sociais, no caso do Aos Brados - e possivelmente de uma série de grupos que não tiveram sucesso em ou não tinham como objetivo a atuação junto ao estado -, as conexões com coletivos de "outros movimentos sociais"13 também são centrais na constituição dos repertórios de atuação. Ademais, a pesquisa aponta para uma mudança nas relações entre ativismos, nas quais tem havido um crescente processo de trocas e aprendizagens, que é uma das estruturas de oportunidades para a ascensão de um enquadramento (frame) que valoriza o combate a todas as formas de opressão e as interseccionalidades.

Esta pesquisa lida com ativistas que tiveram parte importante do início de sua atuação política no movimento LGBTI e, portanto, trata da

13 Coloco o termo entre aspas, porque tento demonstrar como o Aos Brados, na realidade, atua em todos esses movimentos. 
multiplicação de seu sujeito político. Ela se insere também em esforços de compreensão de um contexto mais amplo no qual os movimentos sociais, a partir de sua relação com o Estado, com partidos políticos, e pelas relações que estabeleceram entre si, passaram também a assumir, cada vez mais, um discurso e uma prática que se volta à luta contra distintas formas de opressão. Assim, o olhar para a trajetória do Aos Brados em seus vinte anos de existência me permite preencher lacunas nas discussões sobre as relações entre movimento negro e movimento LGBTI. Contudo, seu principal objetivo é contribuir para o debate acerta das conexões entre redes de relação, oportunidades políticas, e a produção e adoção de repertórios e enquadramentos. Portanto, uma das hipóteses que perpassa este texto é a de que a mudança nas estruturas de oportunidade e nas redes de relação estão fortemente associadas à adoção de novos repertórios e enquadramentos ou a reinterpretação de antigas formas de fazer política a partir do novo contexto. Contudo, ressalta-se o papel fundamental das relações entre distintas formas de ativismos, bem como das próprias organizações ativistas, em pressionar o governo para que suas demandas sejam atendidas, incluindo a adoção de uma gramática que valoriza ideias como interseccionalidade e/ou transversalidade.

\section{De "LGBTI periférico" a "LGBTI negro e periférico"}

O Aos Brados pode ser definido como um grupo formado por sujeitos que se compreendem ou são compreendidos a partir de diferentes orientações sexuais e identidades de gênero que compõe o acrônimo LGBTI. ${ }^{14}$ Pesquisas sobre esse movimento brasileiro têm chamado a atenção para as disputas internas e discussões políticas resultantes do papel que homens gays ocupam em organizações e grupos LGBTI (Facchini, 2005, MacRae, 1990). Essas tensões têm resultado em acusações de que o movimento seria GGGG (Bulgarelli, 2018). Nessa substituição, ativistas lésbicas, transexuais, travestis, intersexo e bissexuais criticam

14 Contudo, não tive contato com nenhum militante intersexo nem soube da participação de militantes que assim se identificam no grupo. 
a centralidade dos homens gays no movimento, bem como os processos pelos quais as demais identidades são apagadas. Já o Aos Brados, desde sua fundação, tem mulheres como figuras centrais: as principais lideranças eram lésbicas (Lúcia e sua companheira, Ana), que eram também as editoras do Jornal Aos Brados, uma das principais formas de atuação do grupo em sua primeira fase. Após o término de sua relação e do afastamento de Ana do grupo, em 2008, Lúcia continuou sendo uma importante liderança, dividindo esse papel com outras mulheres, sendo elas, na atualidade, Joana e Camila.

Como Lúcia ressalta, ela é uma mulher negra, lésbica e gorda, com pouco mais de 40 anos de idade, uma lésbica negra e caminhoneira que pisa forte, em suas próprias palavras. Com voz grave e cabelos raspados ou muito curtos, é possível dizer que ela tem uma performance de gênero que tende para o que se entende como "masculino". Em suas apresentações públicas, é também comum que ela ressalte o fato de ser periférica, petista (filiada ao Partido dos Trabalhadores) e religiosa de matriz africana. Joana é uma mulher cis negra, com cerca de 50 anos de idade, que atua como funcionária pública em uma escola municipal de um bairro periférico da cidade. Ela passou a atuar no grupo por intermédio de Lúcia, que foi sua companheira durante boa parte da realização desta pesquisa, e de Marcelo, seu irmão. Em nenhum momento, Joana expressou sua compreensão no que diz respeito à sua orientação sexual. Quando passou a se engajar nas reuniões do grupo, em meados de 2014, ela se definia como uma aliada dos LGBTI e ressaltava sua participação como um apoio a seu irmão, que é gay. Mais tarde, contudo, passou a se relacionar com Lúcia e a se apresentar como militante. Camila é uma ativista transexual. Ela é negra e também possui cerca de 50 anos de idade, é enfermeira e tem um cargo em um grande e prestigioso hospital da cidade. Dentre as atuais lideranças do grupo, ela é a única com ensino superior completo. Ela teve seus primeiros contatos com o Aos Brados em meados dos anos 2000 e passou a atuar no grupo de maneira mais orgânica por volta de 2013. Ainda que Lúcia compartilhe suas responsabilidades com Joana e Camila, ela ainda é 
considerada pelos membros como a principal figura de liderança. É ela quem geralmente é convidada a falar sobre o grupo em espaços como mesas, debates, oficinas e workshops.

No que diz respeito à composição do Aos Brados, o número de membros variou muito no decorrer dos anos. Em 2016, o grupo contava com um bom número de ativistas, com cerca de vinte a trinta pessoas circulando mensalmente pelas reuniões. Dentre eles, naquele momento, a maioria era formada por jovens gays que atuavam ou aspiravam atuar como drag queens. ${ }^{15}$ Recentemente, o grupo tem sido formado por não mais que oito pessoas, sendo que algumas delas frequentam muito pouco as reuniões, ajudando esporadicamente em algumas das atividades. Além dos membros "mais oficiais", o grupo conta também com uma extensa rede de parceiros e de ativistas que atuavam mais ativamente no passado e que, hoje, colaboram com a organização e realização de suas atividades. É também comum que sujeitos que já estiveram no grupo no passado, apesar de não participarem das reuniões e frequentarem muito pouco as atividades organizadas pelo Aos Brados, se apresentem como membros do grupo.

Em relação às mudanças no número de pessoas, tanto em 2014, quando conheci o Aos Brados, quanto em 2016, havia um grande número de homens gays e uma presença reduzida de mulheres lésbicas e de mulheres transexuais. Isso é interessante, pois, como apontaram três entrevistadas que estão no grupo desde seus primórdios, até meados de 2008, mulheres lésbicas e bissexuais sempre estiveram muito presentes, chegando algumas vezes a ser maioria entre os militantes. Na atualidade, o Aos Brados tem voltado a contar com um número equivalente de pessoas do gênero masculino e feminino. É importante ressaltar que, mesmo nesses momentos em que o grupo carecia de presença feminina

15 Dentre esses jovens, havia duas pessoas que, em diferentes momentos, se concebiam como travestis e, em outros, como homens gays. 
marcante, era comum que Lúcia fosse considerada uma liderança importante, sendo sempre consultada nas tomadas de decisão. ${ }^{16}$

Essa digressão sobre a composição do grupo nos mostra como é complexo traçar uma espécie de perfil sociológico do Aos Brados e de seus integrantes. Isso ocorre porque as pessoas têm movimentos de aproximação e de afastamento, tornando difícil definir os sujeitos que são considerados membros e aqueles considerados parceiros ou colaboradores. Mesmo assim, é importante mencionar que muitos dos sujeitos que transitaram pelo Aos Brados se identificavam ou eram identificados como negros. Grande parte deles habitava bairros considerados periféricos, afastados do centro da cidade e encontrava-se em condições precárias de trabalho, em sua maioria trabalhando de maneira informal. Havia também um grande número de desempregados. A composição etária era heterogênea, em uma faixa que varia dos 18 aos 50 anos de idade. Esses dados são relevantes porque demonstram que essas condições de precariedade são também importantes para compreender a alta variação no número de membros presentes nas atividades, bem como a participação esporádica daqueles que se encontravam em maior estado de vulnerabilidade financeira. ${ }^{17}$

O Aos Brados surgiu em 1998, a partir de desavenças de alguns militantes que faziam parte do Identidade, grupo ativista mais antigo em

16 É importante ressaltar também que essa inconstância no número de ativistas está ligada a desavenças pessoais. Embora tenha existido pessoas que deixaram o grupo por discordâncias políticas, a maioria dos casos que acompanhei foi motivada por questões pessoais. O caso mais emblemático foi o de Ana, que era companheira de Lúcia e deixou o Aos Brados depois que a relação das duas terminou. Devido as dimensões do artigo, não é possível explorar essas questões aqui. Ainda que não fosse o foco da pesquisa, explorei algumas delas em meu livro (Zanoli, 2020).

17 Ademais, diferentemente de outros coletivos com os quais o Aos Brados se relaciona - tanto do movimento negro quanto do movimento LGBTI -, o acesso dos ativistas ao ensino superior ainda é tímido. A maioria dos jovens havia cursado o ensino médio ou parte dele, mas poucos chegaram a cursar a faculdade. Camila é a única militante atuante no grupo que possui um diploma de ensino superior. Já Lúcia e Marcelo são estudantes universitários, cursando Ciências Sociais e Psicologia, respectivamente. 
atividade na cidade. Esses militantes, liderados por duas ativistas lésbicas, Lúcia e Ana, organizaram-se em torno da publicação de um periódico, o Jornal Aos Brados (JAB), criado como uma crítica ao modo de atuação do Identidade. A criação do JAB estaria ligada ao foco do Identidade na utilização da internet para se comunicar com redes e grupos ativistas nacionais e internacionais. Para os membros do Identidade que viriam a fundar o Aos Brados, isso excluía os LGBTI periféricos que tinham pouco ou nenhum acesso a internet. Assim, ao romperem com o Identidade, criaram uma publicação com o objetivo de alcançar os LGBTI periféricos excluídos da internet. Esse jornal era distribuído pelos próprios ativistas em comunidades carentes e, além de contar com matérias sobre direitos de LGBTI, discutia questões ligadas a direitos trabalhistas, a movimentos de moradia, dentre outros.

Em seus primeiros anos de atuação, o Aos Brados não se definia como um grupo negro, mas como um grupo LGBTI periférico. Entretanto, isso não significa que a discussão racial não estivesse presente. Na verdade, desde seu surgimento, a ampla maioria dos participantes e fundadores era composta por LGBTI negros. Contudo, havia a ideia no grupo de que a categoria periferia, ou periférico, abarcava também a discussões sobre racismo.

O trabalho de produção do jornal uniu mais pessoas em torno do Aos Brados, o que os levou a buscar um lugar para se encontrar. Mobilizando suas redes de ativismo ligadas aos movimentos de moradia e ao Partido dos Trabalhadores (PT), as fundadoras conseguiram uma sala na sede da Central Única dos Trabalhadores (CUT) de Campinas. As relações com a CUT e o PT e a atuação no Orçamento Participativo de Campinas ${ }^{18}$ em 2002, são ressaltadas pelos interlocutores como impulsionadores da busca pela institucionalização, bem como pela

18 Lúcia foi a primeira conselheira a representar os homossexuais na temática da cidadania no Conselho do Orçamento Participativo de Campinas. Segundo o Jornal Aos Brados, trata-se da primeira vez que o movimento LGBTI organizado participava de um conselho de OP. 
diversificação de sua atuação. Nesse momento, além de atuar a partir do jornal, o grupo passou a realizar também intervenções em comunidades periféricas, as atividades sociais. Essas intervenções consistiam principalmente em debates sobre direitos LGBTI, denominadas de Brados Papo. Como reitero alhures (Zanoli, 2020), assim como acontece na atualidade com a relação do grupo com o movimento negro, os repertórios de atuação com foco na periferia tinham forte influência dos sindicatos, dos movimentos de moradia e dos movimentos periféricos dos quais alguns dos membros do grupo também faziam parte.

Em 2008, o grupo estabeleceu alianças com o ativismo cultural negro e, a partir disso, repensou algumas de suas atividades, passando a atuar principalmente através do que seus ativistas denominam de atividades culturais. Além disso, o grupo, que até então se via como periférico, passou a se autodenominar como LGBTI, negro e periférico. É importante ressaltar, contudo, que essa mudança não foi uniforme: além do afastamento de alguns membros justamente nesse período, dentre os que se mantiveram desde a fundação e passaram por essas mudanças, há aqueles que consideram a discussão da negritude muito importante, mas ressaltam que a periferia seria uma categoria identitária central; já os sujeitos que passaram a participar do grupo depois de 2008 ressaltam a negritude como uma marca, em alguma medida, mais central na constituição da identidade política do grupo.

Esse momento inaugura uma nova fase, na qual o contato com o movimento negro e o aumento da circulação de alguns dos membros por atividades organizadas por coletivos desse movimento não impactou apenas no modo de se identificar do grupo, mas também em seu modo de atuar. Nas próximas seções, ao abordar as atividades culturais, procuro demonstrar como o grupo se apropria de repertórios e gramáticas que circulam no movimento negro, reinterpretando seu próprio modo de atuar, bem como o modo de dar sentido à essa atuação. 


\section{As atividades culturais}

No período de realização da pesquisa, o Aos Brados foi responsável pela criação e realização de diversas atividades culturais. Aqui, analiso duas delas: a Feijoada da Diversidade (ou Fejuka ${ }^{19}$ da Diversidade) e o Pedal@ Bicha, ambas com foco em apresentações que sintetizam o que o grupo compreende como sendo uma cultura LGBTI, negra e periférica. Dessa atividades apenas a Feijoada continua sendo realizada anualmente, tendo sua primeira edição realizada em 2013. Já o Pedal@, foi organizado como parte das comemorações do Mês da Diversidade Sexual de Campinas entre 2011 e 2016. Desde 2016, depois de uma cisão na Associação da Parada do Orgulho LGBTI de Campinas, o grupo tem tido dificuldade em angariar apoio político e financeiro para a realização do evento.

De modo geral, a maior parte dos eventos faz uso de apresentações artísticas variadas, congregando música, dança e performances de drag queens. Essas apresentações são tidas pelo grupo como as manifestações culturais que, em conjunto, produzem o que definem como cultura LGBTI, negra e periférica. A discussão acerca da necessidade de sua realização se utiliza de argumentos ligados à falta de representatividade de sujeitos LGBTI negros em periféricos em espaços tidos como de cultura LGBTI, como as Paradas do Orgulho, bem como da falta de representatividade LGBTI em espaços de cultura negra e periférica. O combate às distintas formas de opressão se daria não apenas a partir da denúncia da falta de representatividade, mas também da ocupação desses espaços por sujeitos LGBTI, negros e periféricos, ou seja, lutando para que esses sujeitos fossem, de fato, representados nesses espaços.

A construção das atividades segue um mesmo padrão. Os primeiros passos costumam ser as reuniões de organização para a escolha da data e do local do evento. O Aos Brados tem preferência por escolher

19 Fejuka é um termo coloquial para se referir à feijoada. 
lugares que sejam diretamente associados a uma de suas bandeiras de luta, como: a Praça Bento Quirino, associada a sociabilidade de jovens LGBTI (Mascarenhas Neto, 2020, Pelúcio e Duque, 2013); o Largo do Rosário, praça que é palco da concentração de diversas manifestações políticas em Campinas; ou ruas como a Francisco Glicério e a Barão de Jaguara, de circulação restrita para negros até meados do século XX (Giesbrecht, 2011a). O grupo costuma também organizar seus eventos em dois tradicionais espaços de cultura negra de Campinas: a Casa de Cultura Tainã e a Fazenda Roseira. ${ }^{20}$

No que diz respeito ao financiamento, as atividades têm sido organizadas em parceria com a Prefeitura Municipal de Campinas (PMC), principalmente com a Secretaria de Cultura. Além dela, uma série de parceiros são mobilizados, destaco: a Comunidade de Jongo Dito Ribeiro (CJDR), a Frente de Mulheres Negras e Campinas e Região (FMNCR), vereadores e membros filiados ao PT e ao Partido Socialismo e Liberdade (PSOL), a CUT e sindicatos da cidade.

Além de promover atividades sobre o Jongo, ${ }^{21}$ como o Pisa na Tradição, a CJDR é responsável por uma série de projetos culturais, como a Feijoada das Marias do Jongo - que celebra as mais velhas da comunidade, congregando apresentações artísticas e o oferecimento de feijoada aos visitantes -, o Arraial Afro-Julino e o Sou África em Todos os Sentidos - um conjunto de atividades artísticas e culturais com o objetivo de valorizar a estética e a cultura afro-brasileira. O local é sede também do Centro de Referência Jongueiros do Sudeste e da Pós-Graduação em Matriz Africana, que oferece cursos de especialização em que se privilegiam não apenas formas de conhecimento acadêmicos, mas também saberes tradicionais.

20 Para uma análise que problematiza as relações entre ativismo e espaço da cidade, confira Mascarenhas Neto e Zanoli (2019).

21 Expressão cultural negra característica do Sudeste brasileiro. A literatura sobre o tema aponta diversas semelhanças entre o Jongo e práticas culturais de povos bantos (Abreu, 2018). 
Já a FMNCR se articulou a partir dos esforços ligados à organização da Marcha Nacional de Mulheres Negras Contra o Racismo e pelo BemViver, realizada em 2015. ${ }^{22}$ Entre 2015 e 2018, o coletivo organizou diversas atividades: como debates, passeatas, workshops, etc.; era responsável também por uma atividade cultural realizada mensalmente: o Sarau das Aliadas, que costumava acontecer na Casa de Cultura Tainã aos domingos. Nele, parceiras e parceiros da Frente declamavam poesia, cantavam rap, dançavam, etc. Dentre os coletivos que faziam parte da Frente, estava o próprio Aos Brados, que trazia seus militantes para participar das atividades, principalmente com apresentações artísticas de mulheres trans e drag queens.

O processo de organização dos eventos do Aos Brados, assim como os de seus diversos parceiros, tem início meses antes de sua realização, com o protocolo de um pedido de apoio à PMC. Nele, reitera-se a importância das atividades a serem realizadas. Nota-se, que as parcerias entre o Aos Brados e a PMC diferem da maioria daquelas realizadas por outros coletivos LGBTI. Ainda nos anos 1990, os programas de enfrentamento à epidemia de HIV/Aids foram centrais na consolidação das relações entre o movimento LGBTI e o Estado e na institucionalização do movimento (Facchini, 2005). Desse modo, as políticas de saúde foram, pelo menos até meados dos anos 2000, importantes canais de interlocução entre o Estado e movimento. O caso campineiro não é muito diferente: nele, as políticas de enfrentamento à epidemia de HIV/ Aids foram centrais na institucionalização do Identidade, coletivo mais antigo em atividade em Campinas. Já o Aos Brados teve pouco interesse em atuar desse modo.

Esse enfoque tem levado o grupo a adotar gramáticas que circulam no campo das políticas culturais, principalmente aquelas voltadas às comunidades tradicionais e comunidades negras. Assim, no documento

22 A marcha foi uma iniciativa de distintos coletivos de mulheres negras do país e ocorreu em Brasília (Gomes, 2019). 
enviado à prefeitura, reitera-se que a feijoada é preparada de modo ritual e ressalta-se a importância da realização do evento, uma vez que promove o encontro de jovens LGBTI, negros e periféricos com suas raízes e tradições. Nos diversos pedidos de apoio preparados todos os anos, é recorrente a afirmação de que devido ao preconceito sofrido por esses jovens, eles tendem a ter pouco contato com suas raízes e tradições e que pode afetar sua autoestima. Assim, o próprio reencontro de LGBTI negros com suas raízes e sua ancestralidade é tomado como uma das ferramentas pela qual se lutaria ao mesmo tempo contra o racismo e a LGBTfobia.

No caso do Aos Brados, o investimento nas políticas culturais e a utilização de sua gramática estão relacionados, principalmente, à circulação de alguns ativistas por espaços de cultura negra. Alguns deles já possuem histórico de apoio financeiro e institucional obtidos a partir de políticas culturais, colaborando com que seus membros conheçam os meandros da burocracia institucional relacionados a tais políticas, principalmente no que diz respeito ao Programa Pontos de Cultura ${ }^{23}$ e ao ProAC. ${ }^{24}$ Alguns desses grupos têm parte de suas atividades financiadas por editais ligados à cultura, o que possibilita que parcela de seus membros atue profissionalmente dentro dos coletivos. O investimento do Aos Brados nas políticas culturais, dentre outros motivos, se dá pelo entendimento de que é necessário que suas atividades sejam financiadas para possibilitar uma atuação profissional na promoção da cultura LGBTI, negra e periférica; na inclusão de jovens LGBTI negros e periféricos no mercado artístico; bem como, no combate ao racismo, LGBTfobia e classismo. Assim, o Aos Brados tem buscado se profissionalizar

23 Iniciativa do Ministério da Cultura durante a gestão de Gilberto Gil, no governo Lula. Os pontos de cultura são coletivos ou entidades culturais que tem reconhecimento do governo Federal e apoio financeiro para sua atuação.

24 O ProAC (Programa de Ação Cultural) é mantido pela Secretaria de Cultura do Governo do Estado de São Paulo que, através de distintas iniciativas, fomenta a produção cultural no estado. 
para poder concorrer também nos editais públicos citados anteriormente. Essa profissionalização consiste, principalmente, em participar de atividades de formação organizadas por coletivos negros que já foram agraciados com financiamentos nos referidos editais.

Assim, nota-se que, ainda que existam conflitos, menos do que uma competição mais acirrada, como parece sugerir parte da literatura, vemos relações de cooperação entre os movimentos. Ressalto, por exemplo, o fato de que, para alguns coletivos do movimento cultural negro, o Aos Brados é uma espécie de represente dos LGBTI negros, o que faz com que o grupo seja instigado a concorrer em mais de edital, tanto aqueles voltados a manifestações culturais negras, quanto aqueles direcionados a manifestações culturais LGBTI. Estes últimos, no caso do estado de São Paulo, foram criados a partir da pressão de ativistas por meio da Conferência Estadual LGBTI e sugerem um aprendizado de outros coletivos LGBTI com movimentos que já contavam com fomento à cultura, como os povos tradicionais e a população negra. Tendo isso em mente, passemos agora à breve descrição da primeira dessas atividades, o Pedala Bich@.

\section{Pedala Bich@ - a pedalada da diversidade}

Campinas era conhecida, no passado, pela crueldade dos senhores de escravos, pela recusa em aceitar a abolição da escravidão e pela restrição da presença de pessoas escravizadas e de pessoas negras livres nos espaços públicos. Mais tarde, a cidade passou por transformações urbanas marcadas pela expulsão da população negra das regiões centrais para as periferias (Martins, 2016; Giesbrecht, 2011a). Com o objetivo de não permitir que esses processos de exclusão caíssem no esquecimento, o Aos Brados criou o pedala Bich@. O evento costumava acontecer aos domingos e, em suas primeiras edições, consistia em duas partes: um passeio ciclístico pelo centro da cidade e apresentações em um palco no Largo do Rosário. Entre 2011 e 2015, o passeio circulava por importantes ruas da história de segregação racial de Campinas: a Francisco Glicério 
e a Barão de Jaguara. A primeira, nomeada em homenagem a um abolicionista, tinham uma de suas calçadas restritas a pessoas brancas até meados do século XX. As proibições na Barão de Jaguara eram ainda piores: na rua em questão, pessoas negras livres, assim como aquelas escravizadas, eram proibidas de transitar. Martins (2016) reitera que, ainda que essas restrições tenham acabado legalmente com a abolição da escravidão, a segregação se manteve. Desse modo, como reiterado na abertura do evento: ocupar essas ruas com corpos negros, periféricos e LGBTI é um ato político.

Geralmente, aqueles participantes do evento que não traziam suas bicicletas esperavam o fim do passeio ciclístico aglomerados em volta do palco no Largo do Rosário. Lúcia era a apresentadora. Em 2015, em seu discurso de abertura que antecedeu as apresentações, ela lembrou que pessoas negras e pobres continuavam não sendo bem-vindas nas cercanias do centro. Além disso, enfatizou que LGBTI, por serem potenciais vítimas de violência, se vêm privados de seu direito de demonstrar afeto em público, salientando que o Brasil é o país que mais mata LGBTI no mundo. Com isso, ela destacava a necessidade de que mais pessoas ocupassem as ruas junto ao Aos Brados para combater a segregação espacial imposta a LGBTI, negros e periféricos. Ela criticou também as políticas de gentrificação que transformaram antigas vizinhanças negras tradicionais em bairros brancos e elitizados.

Em 2016, último ano de realização do pedala Bich@, Lúcia introduziu os artistas que se apresentariam no show de encerramento, em sua maioria, drag queens. Em cada uma das edições acompanhadas, ao apresentar os artistas, a ativista enfatizava suas origens periféricas, nomeando os bairros de onde vêm. Essa é uma estratégia comum nos eventos que o Aos Brados realiza e nos organizados por seus parceiros, como o Sarau das Manas e o Sarau das Aliadas, por exemplo. Geralmente, ela é utilizada para marcar a origem periférica dos artistas, ou, ainda, suas conexões com ativistas negros ou LGBTI. Ela costuma reiterar também que artistas LGBTI negros e periféricos são constantemente 
excluídos do mercado de entretenimento, principalmente se decidem realizar performances associadas à cultura negra. Assim, os eventos eram também apontados como possibilidades de divulgação dos trabalhos para artistas LGBTI, negros e periféricos. Essa divulgação é entendida como uma das ferramentas que o grupo possui para lutar contra distintas formas de opressão, uma vez que, ao trazer artistas, o grupo lutava contra a invisibilização desses sujeitos.

Naquele ano, a atividade foi realizada na Estação Cultura, um projeto mantido pela Secretaria de Cultura de Campinas em uma antiga e desativada estação de trem da cidade. A relocação aconteceu em decorrência de obras nas ruas pelas quais o evento circulava. Em um primeiro momento, a mudança foi vista como um problema. Entretanto, logo foi repensada como algo positivo: os ativistas decidiram ressaltar que estavam realizando sua atividade na Casa do hip-hop, um movimento parceiro e que, por isso, deveriam aproveitar tal parceria. Foi proposto, então, que as performances dialogassem mais com o hip-hop. E que, para tal, além de trazer apresentações da rapper feminista Luana Hansen, era preciso também que as drag queens incluíssem o hip-hop em suas performances.

Essa proposta não foi feita sem discussão. Em uma das reuniões, alguns ativistas lembraram que, ainda que se tratasse de um aliado do Aos Brados, o hip-hop é muitas vezes apontado como uma cultura masculina e heterossexual. ${ }^{25}$ Assim, ao ocupar a Casa do Hip-hop, a proposta do grupo era mostrar que LGBTI também produzem hip-hop e cultura de periferia. Desse modo, através de suas atividades culturais, como o Pedala Bich@, além de produzir o que compreende como sendo uma cultura LGBTI, negra e periférica, o Aos Brados se engaja na disputa de significados associados a certos espaços. Em seu formato original, o

25 Apesar de seu caráter político, Félix (2005) ressalta que muitas das letras no hip-hop podem ser consideradas machistas. Ademais, Luana Hansen, no documentário Cinco Vezes Luana, destaca o preconceito que sofre no meio musical do rap por ser mulher. 
Pedala Bich@ foi pensado para disputar o espaço por meio da ocupação e da rememoração de histórias de segregação. Quando o grupo moveu a atividade para a Estação Cultura, seus ativistas se engajaram em uma disputa espacial distinta: ao apresentar artistas LGBTI realizando performances associadas à cultura hip-hop, os ativistas do grupo disputam significados associados à cultura hip-hop, ao fazerem isso na Casa do Hip-hop, eles também disputam significados associados àquele espaço.

A partir da descrição do Pedala é possível apontar que o Aos Brados opera a partir da junção de repertórios de atuação característicos de dois dos movimentos sociais dos quais faz parte: o movimento LGBTI e o movimento negro. As apresentações de drag queens e as passeatas já constam há algum tempo no repertório de atuação do movimento LGBTI, popularizadas principalmente pela realização das Paradas do Orgulho em todo país. Igualmente, a denúncia da violência e da negação do direito de ocupar o espaço público é comumente levantado nas Paradas e em outros protestos do movimento, como os beijaços, por exemplo.

As passeatas também são repertórios importantes do movimento negro no Brasil. Flávia Rios (2012) ressalta que, além das próprias passeatas, recentemente, outro importante repertório do movimento negro tem sido a disputa pelas narrativas do passado. Em sua análise da Marcha Noturna pela Democracia Racial, organizada na capital paulista desde 1996, ela compreende a passagem dos manifestantes por espaços específicos da cidade como uma "encenação da história”, na qual rememoram fragmentos que vão do período escravocrata à fundação do MNU e reescrevem a história a partir da importância e centralidade das lideranças negras na luta contra o racismo. Igualmente, militantes do movimento negro de Campinas ressaltaram a importância da ressignificação da história negra e dos espaços negros da cidade. Nesses eventos, a principal discussão dizia respeito à recuperação da memória espacial da população negra da cidade por duas vias: lembrar os espaços dos quais eram segregados, além de rememorar espaços positivos à comunidade negra local, como antigas casas de personalidades negras, 
centros de cultura, terreiros de umbanda e candomblé, espaços de lazer e sedes de organizações políticas.

Portanto, o que vemos na atuação do Aos Brados com o Pedala Bich@ é a junção de repertórios de atuação do movimento negro e do movimento LGBTI, que são ressignificados a partir do que o grupo define como suas bandeiras de luta. Isto é, ao construir uma ponte entre pautas dos movimentos dos quais faz parte, o Aos Brados reenquadra questões caras e reinterpreta repertórios vindos de ambos a partir desses enquadramentos. Assim, negros e LGBTI são apresentados a partir da privação ao direito de estar no espaço público por meio de uma caminhada que busca ressignificar tais espaços de exclusão a partir de sua ocupação.

Flávia Rios (2012) nota que o movimento negro brasileiro, ainda que influenciado por estratégias e discursos advindos do exterior, adaptou tais estratégias e discursos ao âmbito local. De modo semelhante, essas junções e reenquadramentos são adaptações que o Aos Brados faz desses repertórios que circulam nas redes ativistas dos quais o grupo faz parte. Fenômeno que resulta das posicionalidades (Hall, 2001) dos ativistas do grupo que, por circularem em distintos campos movimentistas, atuam a partir de um engajamento crítico - ou desidentificações (Munõz, 1999) - com os repertórios dos movimentos nos quais se engajam.

Para dar continuidade à discussão, passemos agora a uma breve descrição da Feijoada da Diversidade.

\section{Feijoada da Diversidade}

Outra atividade central no calendário do Aos Brados é a Feijoada da Diversidade. Entre 2013 e 2016, ela foi realizada nas dependências da Fazenda Roseira. Desde 2017, tem acontecido na sede campineira do Sindicato Unificado dos Petroleiros de São Paulo. Contudo, aqui, é nas versões realizadas na Fazenda que me atenho, com foco nas edições de 2015 e 2016. 
O sol começava a se por quando Jane, uma jovem drag queen que atuava no Aos Brados, e Carlos, seu namorado e bailarino, foram anunciados por Lúcia, apresentadora da edição da feijoada de 2015. Ao ritmo de um cavaquinho, o primeiro a subir ao palco foi Carlos, que vestia calça, paletó e chapéu brancos, além de um pano vermelho em volta da cintura, representando Zé Pelintra. Com passos lentos que lembravam uma espécie de transe, ele dançava segurando uma vassoura ao som da música com mesmo nome da entidade. Assim que a terceira estrofe foi cantada, a canção deu lugar a "O Canto da Cidade”, de Daniela Mercury, e Jane subiu ao palco utilizando vestido e turbante brancos. Seu objetivo era representar uma girante. Assim que ela acabou de dublar os trechos da letra: "a cor dessa cidade sou eu, o canto dessa cidade é meu”, a música mudou novamente, para outra canção de Daniela Mercury, "Ilê Pérola Negra", um tributo ao bloco afro soteropolitano Ilê Ayê. Em uma mudança brusca, Jane, que tirou o vestido branco e o turbante, revelou um maiô cravejado de pedras, passando a dançar samba.

Não foi à toa que a performance de Jane abriu o conjunto de apresentações de drag queens naquela noite. Na umbanda, "seu Zé Pilintra ${ }^{26}$ é uma das representações mais populares de Exu, caracterizado por terno branco, gravata vermelha, cravo na lapela [e] chapéu caído na testa” (Magnani 1991, p. 47). Magnani reitera também que apesar de ser muitas vezes equivocadamente associado ao mal, Seu Zé Pelintra é uma figura heroica que socorre os necessitados. Como me relatou Lúcia mais cedo naquele dia, Exu, o mensageiro dos orixás, é o responsável por trazer as deidades do continente africano em celebrações ligadas ao candomblé. Portanto, a homenagem a Seu Zé Pilintra era também uma tributo a Exu e funcionava como um pedido de proteção e uma demonstração de respeito à entidade.

A letra da música faz referência ao “canto e à dança negra” e ao e ao bloco afro soteropolitano Ilê Aiyê. Além disso, trata-se de um axé, incluído no rol de ritmos associados à tradição negra que o Aos Brados

26 Por se tratar de uma divindade de caráter popular, a grafia de seu nome pode variar. 
utiliza em seus eventos. Essa não foi a única vez que Jane apresentou seu repertório de músicas associadas à cultura negra em uma atividade do Aos Brados. Na edição de 2016 da Fejuka da Diversidade, vestindo um maiô com franjas e uma peruca com cabelos escuros levemente encaracolados, ela sambou ao som de "Se acaso você chegasse", na voz de Elza Soares. No fim dessa apresentação, a artista ressaltou seu orgulho em homenagear uma cantora preta.

Ao terminar suas apresentações nas atividades do Aos Brados, Jane faz publicações emotivas em sua página no Facebook, agradecendo a oportunidade e ressaltando que adora apresentar divas negras e a própria cultura negra. Assim como outros jovens do grupo, em conversas informais, ela me confessou que é evangélica, religião na qual algumas vertentes consideram que práticas religiosas africanas ou afro-brasileiras são relacionadas ao demônio, mas que acredita ser importante apresentar ritmos musicais e letras que valorizam traços da cultura negra como o candomblé, por exemplo.

Além de Jane, outra drag queen do Aos Brados se apresentou no evento: Júlia, uma das poucas que não se considera negra. ${ }^{27}$ Em sua apresentação, ela vestia roupas brancas: um turbante e uma saia longa, representando uma baiana. A música dublada foi "O Canto das três raças", composta por Mauro Duarte e Paulo César Pinheiro e imortalizada na voz de Clara Nunes. ${ }^{28}$ A versão dublada por Júlia era a interpretada por

27 Ainda que não se perceba como negra, em certo evento, quando ela afirmou ser branca, algumas mulheres negras presentes contestaram tal colocação, argumentando que ela era uma pessoa negra com a pele clara.

28 Clara Nunes construiu parte de sua carreira musical utilizando referencias do candomblé e da umbanda, tendo se convertido para essa última religião. Para Bakke (2007), a diferença entre Nunes e outros sambistas dos anos 1970 estava no fato de que ela não apenas incorporou em seus trabalhos uma iconografia que faz referência às religiões afro-brasileiras, mas discutia abertamente sua pertença à umbanda. (Bakke, 2007). A cantora é uma figura tão representativa na umbanda que uma casa de culto na cidade de Sorocaba, no estado de São Paulo, a homenageia. Como ressaltado no documentário "A tal guerreira" de Marcelo Caetano, nesse templo, Clara é cultuada como Iansã 
Ellen Oléria, cantora negra que tem despontado na música brasileira e muito valorizada pelo Aos Brados. Percebe-se que Nunes aprece como uma referência à umbanda. Assim, se a própria feijoada servida no evento e preparada de modo ritual é acionada ao mesmo tempo como uma referência ao candomblé de modo particular, e à cultura negra de modo geral. Nas apresentação de Jane e Júlia, seu Zé Pilintra e Clara Nunes são mobilizados, ao mesmo tempo, como referentes à umbanda e à cultura negra.

Em 2016, Júlia foi também a apresentadora da feijoada, antes de finalizar o evento ela disse algumas palavras:

Antes de mais nada, eu gostaria de agradecer a Fazenda Roseira por nos receber novamente nesse ano. Como vocês devem saber, é sempre um prazer trabalhar com vocês. Eu gostaria de dizer que esse espaço aqui é muito importante para nós. Não que eu esteja criticando as casas noturnas onde trabalho, afinal, são elas que pagam meu salário. Contudo, aqui nós temos o direito de criar, temos o direito de apresentar canções brasileiras e canções que celebram a cultura afro-brasileira.

Como Rubens Mascarenhas Neto (2020) nota, as jovens drag queens de Campinas circulam por redes que conectam ativistas e pessoas ligadas ao empresariado GLS $^{29}$ da região. Suas apresentações em atividades do movimento LGBTI são vistas tanto como ativismo, uma vez que não costumam receber nenhum cachê, quanto como oportunidades de divulgação de seu trabalho e de conquistar, com isso, melhores posições no mercado de entretenimento. Ainda que exista algum espaço para experimentações nas apresentações realizadas em casas noturnas, ao atuar nas atividades do Aos Brados, muitas das artistas tendem a investir em uma estética que valorize a negritude, em detrimento de uma estética embranquecedora mais presente nas boates.

29 Sigla para: gays, lésbicas e simpatizantes. O termo é utilizado para se referir ao mercado segmentado voltado à população LGBTI no Brasil (França, 2012). 
Além disso, em se tratando de uma atividade que busca produzir o que se entende por uma cultura LGBTI, negra e periférica, essas drag queens, que são muitas vezes tidas como o símbolo máximo do que seria a cultura LGBTI, podem realizar performances com músicas em português e, principalmente, personificar cantoras brasileiras negras, ou músicas de origem afro-brasileira, como o samba, costumeiramente desprezado nos shows realizados nas boates. Além do investimento em estéticas negras ou africanas e em ritmos afro-brasileiros como o samba, ou afro-americanos como o R\&B, as apresentações das drag queens costumam ser influenciadas também pelas religiões de matriz africana, como o candomblé e a umbanda.

A utilização de uma estética ligada às religiões de matriz africana está diretamente associada a importância do candomblé e da umbanda nas redes ativistas pelas quais o Aos Brados circula. Essas religiões são tidas como centros importantes na afirmação da identidade negra e no contato com a ancestralidade. Não se trata de uma questão circunscrita ao movimento local. Como aponta Flávia Rios (2014), setores do movimento negro têm valorizado as religiões de matriz africana desde meados dos anos 1970, ressaltando sua importância na afirmação da identidade negra. Assim, não é incomum que as artistas se vistam com roupas que fazem referência a algum orixá, ou homenageiem um espírito guia, como seu Zé Pilintra.

Ademais, Giesbrecht (2011b) ressalta também a importância da música e da dança como símbolos diacríticos do que se compreende como cultura afro no ativismo local. Em sua análise de grupos culturais afro ${ }^{30} \mathrm{em}$ Campinas, ela ressalta que o que garantia um caráter afro a tais atividades eram apresentações musicais de origem negra ou afro-brasileira. Esse seria o caso, por exemplo, do Arraial Afro-Julino, organizado pela

30 Grupos culturais afro era o termo utilizado durante a pesquisa de Érica Giesbrecht pelos mesmos atores que têm se definido como ativistas culturais negros em minha pesquisa. 
CJDR. Segundo a antropóloga, apesar da origem europeia, as apresentações culturais afro eram mobilizadas pelo grupo como modo de ressignificar suas festas juninas.

Em artigo sobre o que chama de movimentos "afro-culturais", Ana Cláudia Cruz da Silva (2009) se propõe a discutir a noção êmica de cultura desses grupos. Seu objetivo é entender se existe uma visão que relaciona a cultura à política. A partir de material comparativo sobre três coletivos, Silva propõe que é possível falar de um continuum de interpretações. Em uma das pontas, estaria a ideia que vê na cultura um meio para a prática política, na outra, a cultura seria um fim em si mesma. Neste caso, a luta para continuar "fazendo cultura” acaba por politizar a própria cultura. No caso aqui estudado, é possível afirmar que o Aos Brados opera uma ideia de cultura que a pensa em relação à política e que estaria em uma posição intermediária do continuum proposto por Silva.

Além das apresentações de drag queens o evento conta com apresentações de outras artistas, em sua maioria LGBTI, negros e periféricos, mas há também espaço para que parceiros do grupo que não se compreendam como LGBTI. No geral, tais atividades podem ser definidas como manifestações negras ou manifestações periféricas. Ressalto aqui as apresentações da rapper lésbica e feminista Luana Hansen, com músicas que denunciam o machismo, o racismo e a lesbofobia, além de uma série de artistas LGBTI negros locais que buscam oportunidades para divulgar seu trabalho. Ademais, o evento costuma contar também com rodas de jongo e apresentações de grupos culturais da cidade que cantam samba, hip-hop, além de outras manifestações tidas como tradicionalmente negras.

A partir das atividades aqui apresentadas, podemos notar um forte influência do movimento negro não apenas na adesão de um discurso ligado à cultura, mas nas próprias formas de atuar e na identidade política do grupo. Ou seja, além de valorizar a cultura como política, o 
grupo passou também a dialogar com o movimento e a repensar certas atividades como culturais, como é o caso das apresentações de drag queens, que já eram realizadas desde seu surgimento. Não obstante, o contato com o movimento negro foi central em processos subjetivos a partir dos quais alguns dos integrantes do grupo passaram a se compreender também enquanto negros. Ademais, vemos também um forte investimento na estética como forma específica de combater o racismo em meio a LGBTI e a LGBTIfobia em meio aos demais sujeitos políticos com os quais se relaciona. Portanto, podemos dizer que existe um aprendizado mútuo. Isto é, o grupo, ao “emprestar” certos repertórios do movimento negro, os remodela com o objetivo também de "ensinar" esse movimento discussões provenientes do movimento LGBTI.

\section{Conclusão}

Ao analisar as relações que dão origem à mudança na identidade política e na forma de atuar do Aos Brados, procurei demonstrar como a cultura passa a figurar no repertório político de um grupo que se compreende como LGBTI, negro e periférico. Fato que ocorreu em 2008, quando seus ativistas começaram a ter fortes conexões com o movimento cultural negro. Por esse motivo, ao invés de oferecer uma definição teórica do conceito de cultura, procurei analisar os significados êmicos que a noção assume. Realizar tal tarefa implica compreender o processo por meio do qual o Aos Brados produz o que compreende como sendo uma cultura LGBTI, negra e da periferia. ${ }^{31}$

Como procurei demonstrar, ao mesmo tempo em que o grupo procura lutar pelo direito de jovens LGBTI negros e periféricos de atuarem no mercado de entretenimento e em outros espaços de cultura por meio do que entendem como práticas culturais - cantos, danças, performances de drag queens -, o que pode ser definido como uma luta pelo direito de fazer cultura, os ativistas lutam também contra diversas formas

31 Para uma discussão mais detalhada acerca dos usos políticos do conceito de cultura conferir: Zanoli (2020) e Giesbrecht (2011a, 2011b). 
de opressão com suas apresentações culturais. Segundo eles, as práticas culturais têm como objetivo tanto a consolidação e a afirmação da identidade de sujeitos LGBTI, negros e periféricos, como o combate à homofobia, ao racismo e a outras formas de opressão.

No caso da homofobia, por exemplo, esse combate é feito ao mostrar que artistas LGBTI também valorizam a cultura negra em suas apresentações. Outra forma importante de luta contra a homofobia são atividades que mostram homens gays se montando de drag, o que apresentaria a cultura LGBTI (o ato de fazer drag) a pessoas que não a conhecem e desmistificaria ideias associadas à homossexualidade. Já o combate ao racismo ocorre pela própria denuncia da falta de representatividade negra em palcos voltados à cultura LGBTI. Do mesmo modo, a afirmação da identidade negra ocorre nos diversos momentos em que o grupo coloca LGBTI em contato com traços da cultura negra e colabora com o reconhecimento de sua identidade como LGBTI negros.

É importante apontar que, assim como o próprio investimento nas políticas culturais, essa ideia de que a cultura seria política circula nas redes do movimento negro nas quais o Aos Brados atua. Não é à toa, por exemplo, que o termo êmico empregado em sua definição é ativismo cultural negro. Além disso, assim como no caso do Aos Brados, na maioria das atividades nas quais estive presente, existia uma discussão sobre o caráter político dos eventos realizados por grupos como a CJDR e os coletivos que atuam na Casa de Cultura Tainã, que, segundo meus interlocutores, tinham como objetivo central o combate ao racismo.

Tanto Flávia Rios (2014), quanto Nilma Lino Gomes (2019) ressaltam a importância de debates relacionados à cultura e à estética negra na afirmação da identidade negra e no combate ao racismo. Rios, por exemplo, ressalta que ele tem estado presente desde meados dos anos 1970. Contudo, Gomes reitera que, a partir dos anos 2000, há uma politização da estética e do corpo negro que é distinta de processos semelhantes ocorridos em períodos anteriores. Ela relaciona essa nova fase às diversas mudanças políticas ocorridas no período e ao processo de absorção, 
por parte do Estado, de algumas das demandas do movimento negro. Tais demandas, traduzidas em políticas públicas, contribuíram com o processo que Amauri Mendes Pereira (2008) chama de "enegrecimento da política”, marcado, dentre outras coisas, pela criação da Secretaria de Políticas de Promoção da Igualdade Racial (SEPPIR), em 2003, e pela consolidação das políticas de reserva de vagas para pessoas negras e indígenas em universidades públicas, denominadas “cotas”. Na mesma direção, houve, pelo menos na primeira década dos anos 2000, um aumento do investimento nas políticas culturais, incluindo aquelas ligadas ao que meus interlocutores chamam de ativismo cultural negro. Esse investimento está diretamente ligado a essa mudança mais ampla e ao fato de que setores do movimento negro tenham investido na cultura como forma de fazer política (Silva, 2009).

Por outro lado, como nos mostra Gomes (2009), os discursos e práticas produzidos em meio ao movimento negro e, principalmente, no bojo dos feminismos negros têm extravasado o que a literatura da ciência política têm costumeiramente definido como "sociedade civil”, atingindo setores antes não organizados da sociedade. Na mesma direção, minha pesquisa de doutorado (Zanoli, 2020) aponta para caminhos semelhantes no que diz respeito ao movimento LGBTI. Portanto, assim como autores ligados aos estudos de movimento LGBTI, (Facchini, 2018, França, 2012), Gomes mostra a importância da internet e do mercado na consolidação de discursos e na disseminação de práticas, principalmente aquelas ligadas a estéticas políticas e à afirmação da identidade negra, ${ }^{32}$ ressaltando que parte desse discurso tem sido produzido fora dos contextos ativistas tradicionais, mas sem, necessariamente, deixar de se relacionar com eles.

32 Por vezes, Gomes faz uso do termo “negros em movimento”, que também aparece nos trabalhos de Gleicy Mailly da Silva $(2017,2018)$ sobre empreendedorismo negro. Nesses trabalhos, Silva ressalta a adesão desses sujeitos a discursos políticos em torno da negritude, sem que eles, necessariamente, se compreendam como parte do movimento negro. Seus interlocutores, preferem ser compreendidos como "negros em movimento". 
Neste artigo, a partir de um foco na atuação do Aos Brados, um coletivo LGBTI, negro e da periferia que atua em uma grande cidade do interior do estado de São Paulo, no Sudeste brasileiro, analisei as mudanças na identidade institucional do grupo, procurando problematizar abordagens recentes acerca do que a literatura brasileira tem chamado de “especificação do sujeito político do movimento”. Demonstrei que o grupo, ao se relacionar com o movimento negro, sobretudo com coletivos que se definem como culturais, passou a repensar não apenas sua identidade política, chamando atenção à sua negritude, mas também a incorporar formas de atuação empregadas por esses coletivos. Nesse sentido, proponho que esse processo de "especificação” do sujeito político é, de fato, influenciado por políticas mais amplas fomentadas pelo Estado, como a promoção de políticas públicas que valorizam as interseccionalidades. Contudo, reitero também que as relações ativistas são, elas mesmas, importantes oportunidades políticas na consolidação de um ativismo interseccional.

\section{Referências}

Abers, Rebecca; Silva, Marcelo e Tatagiba, Luciana (2018). "Movimentos sociais e políticas públicas: repensando atores e oportunidades políticas." Lua Nova, 105, 15-46.

Abers, Rebecca; Serafim, Lizandra e Tatagiba, Luciana (2014). "Repertórios de interação estado-sociedade em um estado heterogêneo: a experiência na Era Lula.” Dados, 57 (2), 325-357.

Abreu, Martha (2018). Canções escravas. Em Schwarcz, Lília e Gomes, Flávio (eds.). Dicionário da Escravidão e Liberdade: 50 textos críticos. São Paulo: Companhia das Letras.

Aguião, Sílvia (2018). Fazer-se no "Estado": uma etnografia sobre o processo de constituição dos "LGBTI" como sujeitos de direitos no Brasil contemporâneo. Rio de Janeiro: EdUERJ. Recuperado de: http://books.scielo.org/id/k8vc4.

Alvarez, Sonia (2014). Para além da sociedade civil: reflexões sobre o campo feminista. Cadernos Pagu, 43. Recuperado de: https://doi.org/10.1590/01048333201400430013. 
Alvarez, Sonia, Jeffrey Rubin, Thayer, Milly, Baiocchi, Gianpaolo, e Laó-Montes, Agustín (eds.) (2017). Beyond Civil Society: Activism, Participation, and Protest in Latin America. Durham: Duke University Press.

Bakke, Rachel Rua Baptista (2007). Tem orixá no samba: Clara Nunes e a presença do candomblé e da umbanda na música popular brasileira. Religião \& Sociedade, 27 (2), 85-113.

Banaszak, Lee Ann. (2005). Inside and outside the state: movement insider status, tactics and public policy achievements. Em Meyer, David S.; Jennes, Valerie, e Ingram, Hellen (eds.). Routing the opposition: social movements, public policy, and democracy. Minneapolis: University of Minnesota Press.

Benford, Robert e Snow, David (2000). Framing Processes and Social Movements: An Overview and Assessment. Annu. Rev. Sociology, 26, 611-39.

Brah, Avtar (1996). Cartographies of Diaspora: Contesting Identities. Londres e Nova Iorque: Routledge.

Braz, Camilo (2014). Provocações queer à “cultura LGBT”. Em Minella, Luzinete, Assis, Gláucia, Funck, Susana (eds.). Políticas e Fronteiras. Tubarão-SC: Editora Copiart, 55-82.

Bringel, Breno (2012). Com, contra e para além de Charles Tilly: mudanças teóricas no estudo das ações coletivas e dos movimentos sociais. Sociologia \& Antropologia, 2 (3), 43-67.

Bulgarelli, Lucas (2018). Alerta textão - Estratégias de engajamento do movimento LGBTI de São Paulo (2015-2016) (Dissertação de Mestrado). Universidade de São Paulo, São Paulo, Brasil.

Butler, Judith (2018). Corpos em aliança e a política das ruas: notas para uma teoria performativa de assembleia. Rio de Janeiro: Civilização Brasileira.

Câmara, Cristina (2002). Cidadania e orientação sexual: a trajetória do grupo Triângulo Rosa. Rio de Janeiro: Academia Avançada.

Crenshaw, Kimberle (1989). Demarginalizing the intersection of race and sex; a black feminist critique of discrimination doctrine, feminist theory and antiracist politics. University of Chicago Legal Forum, 1989, 139-167.

Facchini, Regina (2005). Sopa de Letrinhas? Movimento homossexual e a produção de identidades coletivas nos anos 1990. Rio de Janeiro: Garamond. 
Facchini, Regina (2018). Múltiplas identidades, diferentes enquadramentos e visibilidades: um olhar para os 40 anos do movimento LGBTI. Em Green, James, Quinalha, Renan, Caetano Marcio, Fernandes, Marisa (eds.). História do Movimento LGBTI no Brasil. São Paulo: Alameda Editorial.

Feitosa, Cleyton (2019). Políticas públicas LGBTI no Brasil: um estudo sobre o Centro Estadual de Combate à Homofobia de Pernambuco. Sex. Salud y Sociedad, 32, 90-118.

Felix, João Batista de Jesus (2005). Hip Hop: cultura e política no contexto paulistano (Tese de Doutorado). Universidade de São Paulo, São Paulo, Brasil.

França, Isadora Lins (2012). Consumindo lugares, consumindo nos lugares: Homossexualidade, consumo e subjetividades na cidade de São Paulo. Rio de Janeiro: Eduerj.

Giesbrecht, Érica (2011a). A memória em negro: sambas de bumbo, bailes negros e carnavais construindo a comunidade negra de Campinas. Campinas: Pontes Editorial.

Giesbrecht, Érica (2011b). O passado negro: a incorporação da memória negra em Campinas através das performances de legados musicais (Tese de Doutorado). Universidade Estadual de Campinas, Campinas, Brasil.

Goffman, Erwing (1974). Frame Analysis: An Essay on the Organization of Experience. Harvard University Press.

Gomes, Nilma Lino (2019). O movimento negro educador: saberes construídos nas lutas por emancipação. Rio de Janeiro: Vozes.

Gonzalez, Lélia (1982). O movimento negro na última década. Em Gonzalez, Lélia e Hasenbalg, Carlos (eds.). Lugar de Negro. Rio de Janeiro: Marco Zero.

Hall, Stuart (2001). Que negro é esse na cultura popular negra?. Lugar Comum, 13-14, 147-159.

Lima, Stephanie (2020). A gente não é só negro! Interseccionalidade, experiência e afetos na ação política de negros universitários (Tese de Doutorado). Universidade Estadual de Campinas, Campinas, Brasil.

Lopes, José Sérgio Leite e Heredia, Beatriz (orgs.) (2014). Movimentos sociais e esfera pública: o mundo da participação. Rio de Janeiro: CBAE. 
Lopes, Paulo Vítor Leite (2011). Sexualidade e construção de si em uma favela carioca: pertencimentos, identidades, movimentos (Dissertação de Mestrado). Universidade Federal do Rio de Janeiro, Rio de Janeiro, Brasil.

MacRae, Edward (1990). A construção da igualdade: identidade sexual e política no Brasil da "abertura". Campinas: Editora da Unicamp.

Magnani, José Cantor (1991). Umbanda. São Paulo: Ática.

Martins, Alessandra Ribeiro (2016). Matriz Africana em Campinas: Territórios, Memória e Representação (Doutorado em Urbanismo), Pontifícia Universidade Católica de Campinas, Campinas Brasil.

Mascarenhas Neto, Rubens (2020). Da praça aos palcos: caminhos da construção de uma carreira drag queen. Salvador: Devires.

Mascarenhas Neto, Rubens e Zanoli, Vinícius (2019). Black, LGBTI and from the Favelas: An Ethnographic Account on Disidentificatory Performances of an Activist Group in Brazil. Culture Unbound, 11 (1), 124-140.

Mello, Luiz, Brito, Walderes, e Maroja, Daniel (2012). Políticas públicas para a população LGBTI no Brasil: notas sobre alcances e possibilidades. Cadernos Pagu, 39, 403-429.

Muñoz, José Esteban (1999). Disidentifications: Queers of Color and the Performance of Politics. Minneapolis: University of Minnesota Press.

Nascimento, Érica Peçanha (2011). É tudo nosso! Produção cultural na periferia paulistana (Tese de Doutorado), Universidade de São Paulo, Brasil.

Palmeira, Moacir e Barreira, César (orgs.) (2004). Políticas no Brasil: visões de antropólogos. Rio de Janeiro: Relume-Dumará.

Pelúcio, Larissa e Duque, Tiago (2013). “...Depois querida ganharemos o mundo": reflexões sobre gênero, sexualidade e políticas públicas para travestis adolescentes, meninos femininos e outras variações. Revista de Ciências Sociais, 44 (1), 10-43.

Pereira, Amauri Mendes (2008). Trajetória e perspectivas do movimento negro. Belo Horizonte: Nandyala.

della Porta, Donatella e Diani, Mario (eds.) (2006). Social Movements: An Introduction. London: Blackwell. 
Ribeiro, Djamila (2017). O que é lugar de fala?. Belo Horizonte: Letramento: Justificando.

Rios, Flávia (2012). O protesto negro no Brasil contemporâneo. Lua Nova, 85, 41-79.

Rios, Flávia (2014). Elite política negra no Brasil: relação entre movimento social, partidos políticos e Estado (Tese de Doutorado). Universidade de São Paulo, São Paulo, Brasil. Recuperada de: https://www.teses.usp.br/teses/ disponiveis/8/8132/tde-04022015-124000/pt-br.php.

Rios, Flávia e Regimeire, Maciel (2017-2018). Feminismo negro brasileiro em três tempos: Mulheres Negras, Negras Jovens Feministas e Feministas Interseccionais. Labrys estudos feministas, 2017-2018. Recuperada de: https://www.labrys.net.br/labrys31/black/flavia.htm

Rios, Flávia, Perez, Olívia e Ricoldi, Arlene (2018). Interseccionalidade nas mobilizações do Brasil contemporâneo. Lutas Sociais (PUC SP), 22 (40), 36-51.

Santos, Marcos César Gomes (2015). Rede Afro: quando o movimento LGBTT diz que não e nós afirmamos que sim, há racismo! (Trabalho de Conclusão de Curso). Centro Universitário Salesiano de São Paulo, Campinas.

Silva, Ana Cláudia Cruz da (2009). Militância, cultura e política em movimentos afro-culturais. Revista de Antropologia, 52 (1), 161-200.

Silva, Gleicy Mailly (2018). Cultura negra e empreendedorismo: sensibilidades políticas a reivindicações econômicas e o engajamento através do mercado. Anuário Antropológico, 43 (1), 11-36.

Silva, Gleicy Mailly (2017). Empreendedorismos sociais, negócios culturais: uma etnografia das relações entre economia e política a partir da Feira Preta em São Paulo (Tese de Doutorado). Universidade de São Paulo, São Paulo, Brasil.

Snow, David, Rochford Jr., Burke, Worden, Steven, e Benford, Robert (1986). Frame Alignment Processes, Micromobilization, and Movement Participation. American Sociological Review 51 (4): 464-81. 
Snow, David, Benford, Robert, McCammon, Holly, Hewitt, Lyndi, e Fitzgerald, Scott (2014). The Emergence, Development, and Future of the Framing Perspective: 25 + Since 'Framing Alignment.' Mobilization: An International Quarterly, 19 (1), 23-45.

Tilly, Charles (1993). "Contentious Repertoires in Great Britain, 1758-1834”. Social Science History, 17 (2), 253-280.

Zanoli, Vinícius (2020). Bradando contra todas as opressões! Ativismos LGBTI, negros, populares e periféricos em relação. Salvador: Devires.

\section{Produções Audiovisuais Citadas}

A Tal Guerreira. Direção: Marcelo Caetano. Coprodução: Jurandir Müller. Brasil: Paleo TV, 2008. Recuperado de: http://portacurtas.org.br/filme/?name $=$ a_tal_guerreira.

Cinco Vezes Luana. Direção: Ana Carolina Marques, Gabriel Stocco, Hélène Baras, Inma Benedito, Larissa Teixeira e Laura Jotace. Orientação: Renato Levi. Brasil: CJE/ECA/USP, 2015. Recuperado de: https://www.youtube. com/watch? $\mathrm{v}=$ THEgWyMOIQs. 